\title{
Both Laminin and Schwann Cell Dystroglycan Are Necessary for Proper Clustering of Sodium Channels at Nodes of Ranvier
}

\author{
Simona Occhi, ${ }^{1}$ Desirée Zambroni, ${ }^{1}$ Ubaldo Del Carro, ${ }^{2}$ Stefano Amadio, ${ }^{2}$ Erich E. Sirkowski, ${ }^{3}$ Steven S. Scherer, ${ }^{3}$ \\ Kevin P. Campbell, ${ }^{4}$ Steven A. Moore, ${ }^{5}$ Zulin-L. Chen, ${ }^{6}$ Sidney Strickland, ${ }^{6}$ Antonio Di Muzio, ${ }^{7}$ Antonino Uncini, ${ }^{7}$ \\ Lawrence Wrabetz, ${ }^{1}$ and M. Laura Feltri ${ }^{1}$ \\ ${ }^{1}$ Dibit and ${ }^{2}$ Department of Neurology, San Raffaele Scientific Institute, 20132 Milan, Italy, ${ }^{3}$ Department of Neurology, University of Pennsylvania Medical \\ Center, Philadelphia, Pennsylvania 19104-6077, ${ }^{4}$ Howard Hughes Medical Institute and ${ }^{5}$ Department of Pathology, University of Iowa, Iowa City, Iowa \\ 52242, ${ }^{6}$ Laboratory of Neurobiology and Genetics, Department of Neurology, The Rockefeller University, New York, New York 10021, and 7Department of \\ Oncology and Neurosciences, University “G. d'Annunzio," and Degenerative Diseases Unit, Aging Research Center, Centro Studi Invecchiamento, “G. \\ d’Annunzio" University Foundation, I-66013 Chieti-Pescara, Italy
}

Nodes of Ranvier are specialized axonal domains, at which voltage-gated sodium channels cluster. How axons cluster molecules in discrete domains is mostly unknown. Both axons and glia probably provide constraining mechanisms that contribute to domain formation. Proper sodium channel clustering in peripheral nerves depends on contact from Schwann cell microvilli, where at least one molecule, gliomedin, binds the sodium channel complex and induces its clustering. Furthermore, mice lacking Schwann cell dystroglycan have aberrant microvilli and poorly clustered sodium channels. Dystroglycan could interact at the basal lamina or at the axon-glial surface. Because dystroglycan is a laminin receptor, and laminin 2 mutations [merosin-deficient congenital muscular dystrophy (MDC1A)] cause reduced nerve conduction velocity, we asked whether laminins are involved. Here, we show that the composition of both laminins and the dystroglycan complex at nodes differs from that of internodes. Mice defective in laminin 2 have poorly formed microvilli and abnormal sodium clusters. These abnormalities are similar, albeit less severe, than those of mice lacking dystroglycan. However, mice lacking all Schwann cell laminins show severe nodal abnormalities, suggesting that other laminins compensate for the lack of laminin 2. Thus, although laminins are located at a distance from the axoglial junction, they are required for proper clustering of sodium channels. Laminins, through their specific nodal receptors and cytoskeletal linkages, may participate in the formation of mechanisms that constrain clusters at nodes. Finally, abnormal sodium channel clusters are present in a patient with MDC1A, providing a molecular basis for the reduced nerve conduction velocity in this disorder.

Key words: laminin; Schwann cell; node of Ranvier; microvilli; dystrophic; sodium channels

\section{Introduction}

Nodes of Ranvier contain clusters of voltage-gated sodium channels (Nav), which are essential for saltatory nerve conduction. Laterally, paranodes and juxtaparanodes are enriched in different molecules, making the axolemma polarized (for review, see Poliak and Peles, 2003; Salzer, 2003; Scherer et al., 2004). How local

Received Feb. 10, 2005; revised Aug. 30, 2005; accepted Aug. 31, 2005.

This work was supported by National Institutes of Health Grants NS 045630, NS 041319, and NS 043174 and Telethon (Italy) Grants GGP04019 and GGP030074. We thank Giorgia Dina for excellent technical assistance, ALEMBIC (Advanced Light and Electron Microscopy Biolmaging Center) for image acquisition, Felipe Court for help with image analysis, members of the laboratory for helpful discussion, Fumiaki Saito (Teikyo University School of Medicine, Tokyo, Japan) for his contribution to the production of dystroglycan floxed mice, and Drs. Peter Brophy (University of Edinburgh, Edinburgh, UK), Heinz Furthmayr (Stanford University, Stanford, CA), Elior Peles (Weizmann Institute of Science, Rehovot, Israel), Lydia Sorokin (Lund University, Lund, Sweden), Rupert Timpl (Max Plank Institute, Martinsried, Germany), and James Trimmer (University of California, Davis, (A) for antibodies.

Correspondence should be addressed to M. Laura Feltri, Dibit, San Raffaele Scientific Institute, Via Olgettina 58, 20132 Milan, Italy. E-mail: feltri.laura@hsr.it.

DOI:10.1523/JNEUROSCI.2068-05.2005

Copyright $\odot 2005$ Society for Neuroscience $\quad$ 0270-6474/05/259418-10\$15.00/0 axonal specialization is achieved is mostly unknown. Much evidence indicates that assembly of axonal domains depends on axoglial interactions. Molecule(s) on Schwann cell microvilli bind the nascent Ng-CAM-related cell adhesion molecule (NrCAM)/Neurofascin 186/Nav complex on axons (Vabnick et al., 1996; Lambert et al., 1997; Ching et al., 1999; Lustig et al., 2001), and one such molecule, gliomedin, has been identified recently (Eshed et al., 2005). Furthermore, axonal and glial scaffolds may form molecular barriers that prevent lateral movements (Rosenbluth, 1981; Vabnick et al., 1996; Pedraza et al., 2001). These mechanisms may induce nascent binary Nav clusters and force them to fuse, possibly pushed by elongating Schwann cell processes (Melendez-Vasquez et al., 2001; Gatto et al., 2003). However, it is hard to reconcile these data with the observation that Nav clusters form in the absence of Schwann cell processes in the roots of laminin 2-deficient mice (Deerinck et al., 1997).

Microvilli contain dystroglycan, and its ablation in Schwann cells impairs Nav clustering and reduces nerve conduction velocity (Saito et al., 2003). How dystroglycan promotes clustering is 
Table 1. List of antibodies used

\begin{tabular}{|c|c|c|c|c|c|}
\hline Antigen & Antibody & Species & Clone/name & Dilution & Source \\
\hline$\alpha$-Dystroglycan & $\mathrm{mAb}$ & Mouse & IIH6 & $1: 100$ & K. Campbell \\
\hline$\beta$-Dystroglycan & $\mathrm{mAb}$ & Mouse & 43DAG1/8D5 & $1: 50$ & Novocastra Laboratories (Newcastle upon Tyne, UK) \\
\hline Dystrophin Dp116 & $\mathrm{mAb}$ & Mouse & MANDRA1 & $1: 100$ & Sigma (St. Louis, M0) \\
\hline DRP2 & $\mathrm{pAb}$ & Rabbit & 2164 & $1: 100$ & Peter Brophy (University of Edinburgh, Edinburgh, UK) \\
\hline Ezrin & $\mathrm{pAb}$ & Rabbit & & $1: 30$ & Upstate Biotechnology (Lake Placid, NY) \\
\hline ERM phosphorylated & $\mathrm{pAb}$ & Rabbit & & $1: 50$ & Cell Signaling (Beverly, MA) \\
\hline Caspr & $\mathrm{mAb}$ & Mouse & & $1: 100$ & Elior Peles (Weizmann Institute of Science, Rehovot, Israel) \\
\hline Caspr & $\mathrm{pAb}$ & Rabbit & & $1: 600$ & Elior Peles \\
\hline Laminin $\alpha 1$ & $\mathrm{mAb}$ & Rat & 317 & $1: 2$ & Lydia Sorokin (Lund University, Lund, Sweden) \\
\hline Laminin $\alpha 2$ & $\mathrm{mAb}$ & Rat & $4 \mathrm{H} 8 / 2$ & $1: 100$ & Alexis (San Diego, CA) \\
\hline Laminin $\alpha 4$ & $\mathrm{pAb}$ & Rabbit & & $1: 100$ & Jeffrey Miner (Washington University, St. Louis, M0) \\
\hline Laminin $\alpha 5$ & $\mathrm{pAb}$ & Rabbit & & $1: 400$ & Lydia Sorokin \\
\hline Laminin $\beta 2$ & $\mathrm{pAb}$ & Rabbit & 1117 & $1: 50$ & Rupert Timpl (Max Plank Institute, Martinsried, Germany) \\
\hline Laminin $\gamma 1$ & $\mathrm{mAb}$ & Rat & A5 & $1: 50$ & Chemicon (Temecula, CA) \\
\hline MAG & $\mathrm{mAb}$ & Mouse & & 1:50 & Boehringer Mannheim (Mannheim, Germany) \\
\hline Neurofascin $155+186$ & $\mathrm{pAb}$ & Rabbit & & $1: 1000$ & Peter Brophy \\
\hline Potassium channel Kv1.1 & $\mathrm{pAb}$ & Rabbit & & $1: 100$ & Alomone Labs (Jerusalem, Israel) \\
\hline Radixin & $\mathrm{pAb}$ & Rabbit & $92-4$ & $1: 100$ & Heinz Furthmayr (Stanford University, Stanford, CA) \\
\hline Sodium channel Nav1.6 & $\mathrm{pAb}$ & Rabbit & & $1: 200$ & James Trimmer (University of California, Davis, CA) \\
\hline Sodium channel Nav1.2 & $\mathrm{mAb}$ & Mouse & $K 69 / 3$ & 1:100 & Upstate Biotechnology \\
\hline Sodium channel Pan Nav & $\mathrm{mAb}$ & Mouse & $\mathrm{K} 58 / 35$ & $1: 100$ & Sigma \\
\hline Utrophin & $\mathrm{mAb}$ & Mouse & $\mathrm{DRP} 3 / 20 \mathrm{C} 5$ & $1: 50$ & Novocastra Laboratories \\
\hline
\end{tabular}

mAb, Monoclonal antibody; pAb, polyclonal antibody.

not known. Dystroglycan is a receptor (Ervasti and Campbell, 1993) that connects laminin and agrin in the basal lamina of internodal Schwann cells to an intracellular complex that includes dystrophin isoform 116 (Dp116), dystrophin-related protein 2 (DRP2), periaxin, and actin (Byers et al., 1993; Saito et al., 1999; Sherman et al., 2001). Similarly, dystroglycan may connect the basal lamina to the cytoskeleton of microvilli, forming the glial side of a specific molecular scaffold that restricts the movement of Nav. In this case, a distinct composition of dystroglycan linkage at the node would be expected. Alternatively, because dystroglycan can bind ligands other than laminins, dystroglycan could be on the axoglial interface of microvilli and interact with glial or axonal molecules.

To explore this question, we analyzed the composition of laminins and their linkages at nodes, and compared the phenotype of mice lacking laminins to that of mice lacking dystroglycan in Schwann cells. We show that laminins are abundant in the nodal basal laminas but that, here, the composition of both laminins and of the dystroglycan complex differs from that of internodes. Mice lacking functional laminin 2 (dystrophic) have reduced nerve conduction velocity, enlarged nodes, and poorly formed microvilli, in agreement with previous data and similar to merosin-deficient congenital muscular dystrophy (MDC1A) patients (Shorer et al., 1995; Di Muzio et al., 2003). Dystrophic nodes have Nav clusters of reduced dimension and abnormal shape. Similar Nav clusters are found in an MDC1A patient. These alterations are similar, but less severe, than those of dystroglycannull mice. However, mice lacking all Schwann cell laminins show severe Nav cluster alteration, indicating that other laminins substitute for laminin 2 at nodes. Finally, in dystrophic "naked" roots, where microvilli are absent, Nav clusters are present, as reported previously (Deerinck et al., 1997), but highly abnormal. These data suggest that specific Schwann cell laminins, receptors, and cytoskeletal linkage participate in the formation of a transcellular scaffold important for the assembly of the nodal architecture and provide a molecular basis for the reduced nerve conduction velocity in patients with MDC1A.
Table 2. Laminin trimer composition in adult peripheral nerves

\begin{tabular}{lllll}
\hline Laminin & $\begin{array}{l}\text { Subunit } \\
\text { composition }\end{array}$ & Perineurium & $\begin{array}{l}\text { Endoneurium } \\
\text { (Schwann cell } \\
\text { basal lamina) }\end{array}$ & $\begin{array}{l}\text { Node of } \\
\text { Ranvier }\end{array}$ \\
\hline 1 & $\alpha 1 \beta 1 \gamma 1$ & & + \\
2 & $\alpha 2 \beta 1 \gamma 1$ & + & + \\
8 & $\alpha 4 \beta 1 \gamma 1$ & + & + & + \\
9 & $\alpha 4 \beta 2 \gamma 1$ & & & + \\
10 & $\alpha 5 \beta 1 \gamma 1$ & + & & \\
\hline
\end{tabular}

Trimer distribution is assumed from coincident expression of individual isoforms.

\section{Materials and Methods}

Mice and genotyping. Dystrophic dy2J mice (C57BL/6J-Lama2dy- ${ }^{2 J}$ ) were obtained from the The Jackson Laboratory (Bar Harbor, ME) and maintained by backcrosses with C57BL6/N. Both wild-type (wt) and $d y^{2 J} /+$ were used as control for $d y^{2 J} / d y^{2 J}$ mice. Mice lacking dystroglycan specifically in Schwann cells were produced by crossing P0Cre transgenic mice (mPoTOTCre) (Feltri et al., 2002), with dystroglycan-floxed mice (Moore et al., 2002). DG Flox/Flox//P0Cre mice were used for the experiments, and DG $+/+/ /$ P0Cre or DGFlox/Flox littermates were used as controls. Similarly, mice lacking laminin $\gamma 1$ in Schwann cells were generated by crossing $\gamma 1$ floxed mice (Chen and Strickland, 2003) with P0Cre mice to obtain experimental $\gamma 1$ Flox/Flox//P0Cre mice and $\gamma 1$ Flox/Flox control littermates. Mouse genotyping was performed by PCR analysis of tail genomic DNA (Stephens et al., 1993; Feltri et al., 1999a,b; Chen and Strickland, 2003; Saito et al., 2003). All experiments involving animals were performed according to protocols approved by the Institutional Animal Care and Use Committee of San Raffaele Scientific Institute.

Human biopsy. Sural nerve biopsies from a MDC1A patient and from a patient with an unrelated, acquired inflammatory neuropathy were obtained as described previously (Quattrini et al., 1996; Di Muzio et al., 2003), in accordance with protocols approved by institutional ethical committees. Immunohistochemistry on the MDC1A nerve showed absence of laminin 2 (Di Muzio et al., 2003).

Antibodies. The primary antibodies used are listed in Table 1. Secondary antibodies included the following: fluorescein isothiocyanate 
(FITC)- or tetramethylrhodamine isothiocyanate (TRITC)-conjugated donkey anti-rabbit IgG (1:100); FITC-conjugated donkey antimouse $\operatorname{IgG}(1: 150)$ and FITC-conjugated goat anti-rat IgG were from Jackson ImmunoResearch (West Grove, PA).

Immunohistochemistry on teased fibers and on frozen sections. Sciatic nerves from adult mutant and control mice and from rats; dorsal and ventral roots of $d y^{2 J} / d y^{2 J}$ and control mice; and optic nerves from control mice at postnatal day 11 were dissected and fixed by immersion in fresh ice-cold 4\% paraformaldehyde in PBS for 30 min, and then kept in PBS at $+4^{\circ} \mathrm{C}$ until teasing. For immunofluorescence on unfixed tissues, sciatic nerves were washed in PBS after dissection and teased immediately. For quantitative analysis of Nav, mutant and control nerves were dissected and teased the same day. Single fibers from roots and sciatic nerves were teased apart after removal of the perineurium using fine stainless-steel needles, dried overnight, and stored at $-20^{\circ} \mathrm{C}$. For immunostaining, fibers were permeabilized in cold acetone for $10 \mathrm{~min}$ at $-20^{\circ} \mathrm{C}$. After blocking with $5 \%$ fish skin gelatin, $0.5 \%$ Triton X-100, $0.02 \%$ sodium azide in PBS, fibers were labeled with primary antibodies, followed by appropriate secondary antibodies, washed, dried, and mounted with Vectashield (Vector Laboratories, Burlingame, CA), and analyzed with a confocal microscope (MRC 1024; Bio-Rad, Hercules, CA; or TCS-SP2; Leica, Nussloch, Germany). Because the background fluorescence of mouse monoclonal antibodies on mouse teased fibers can resemble basal lamina staining, we used rat or rabbit antibody for laminin stainings, or rat teased fibers for dystroglycan, Dp116, and utrophin staining, in cases in which only mouse antibodies were available. Immunohistochemistry on frozen sections was performed as described previously (Feltri et al., 2002).

Electron microscopy. The sciatic nerves of wild-type and $d y^{2 J} / d y^{2 J}$ adult mice were removed and fixed overnight at $4^{\circ} \mathrm{C}$ in $2 \%$ glutaraldehyde in $0.12 \mathrm{M}$ phosphate buffer. On the next day, the sciatic nerves were washed in phosphate buffer, osmicated in $1 \% \mathrm{OsO}_{4}$ for $1 \mathrm{~h}$ at room temperature, and then divided into 5-mm-long segments, dehydrated in graded ethanols, infiltrated with propylene oxide and then Epon, and polymerized at $60^{\circ} \mathrm{C}$. Ultrathin sections were stained with lead citrate and photographed with a Zeiss (Oberkochen, Germany) EM10 electron microscope. Semithin morphological analysis of roots and sciatic nerves of dystrophic animals and control littermates was performed as described previously (Wrabetz et al., 2000).

Electrophysiology. Seven $d y^{2 J} / d y^{2 J}$ and three control mice were analyzed at 3 months of age. Mice were anesthetized with tribromoethanol $(0.02 \mathrm{ml} / \mathrm{g}$ of body weight) and placed under a heating lamp to avoid hypothermia. The sciatic nerve motor conduction velocity was obtained with steel monopolar needle electrodes: a pair of stimulating electrodes was inserted subcutaneously near the nerve at the ankle; and a second pair of electrodes was placed at the sciatic notch, to obtain two distinct sites of stimulation, proximal and distal, along the nerve. The compound motor action potential was recorded with an active electrode inserted in muscles in the middle of the paw and a reference needle in the skin between the first and second digits.

Image and quantitative analysis. Figures were prepared using Adobe Photoshop 7, Adobe Illustrator 10, and ImageJ. To quantify the frequency of abnormal clusters, mutant and control nerves were analyzed blindly by two independent investigators using a Leica DM5000 fluorescence microscope: only paranodes belonging to straight fibers and in an optimal focal plane (as identified by Caspr staining of both adjacent paranodes) were chosen, and then the Nav cluster staining at the node
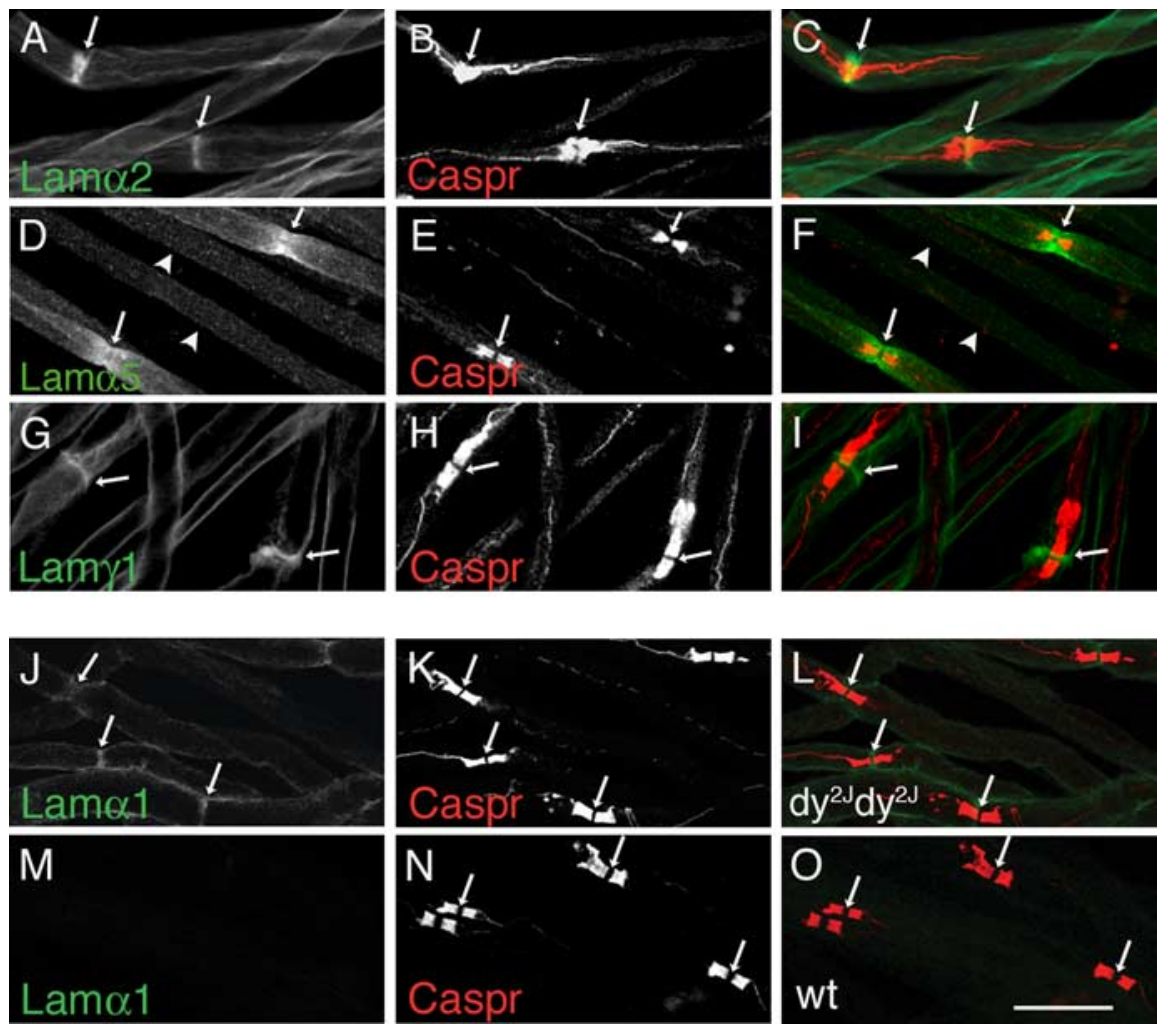

Figure 1. Specific laminin isoforms are present in the basal laminas above nodes of Ranvier. Images of teased fibers isolated anti-Caspr antibody (red; $\boldsymbol{K}, \boldsymbol{N}$ ). The immunostaining reveals the presence of the $\alpha 1$ chain in the nodes of Ranvier of dystrophic mice ( $\boldsymbol{J}$, arrows) where this laminin is normally absent $(\boldsymbol{M})$. Lam, Laminin. Scale bar, $16 \mu \mathrm{m}$.

was classified as normal (rectangular, with square corners, normal width) or abnormal (irregular shape and lacking square corners, diffuse and long, low intensity in every optical plane, or difficult to put into focus). Quantification of the area of Nav clusters in sciatic nerves and roots was made using a laser inverted confocal microscope (Leica TCS-SP2) (FITC, excitation of laser $\mathrm{Ar} / \mathrm{Kr}$ at $488 \mathrm{~nm}$; TRITC, excitation of laser $\mathrm{He} / \mathrm{Ne}$ at $546 \mathrm{~nm}$ ). Nodes were selected using Caspr staining, as above. The gain of $\mathrm{Nav}$ and Caspr fluorescence detection was maintained below the threshold of fluorochrome saturation. $z$-axis-series spanning $\sim 5.5 \mu \mathrm{m}$ were acquired by sequentially scanning (between frames), using a step size of $0.122 \mu \mathrm{m}$. ImageJ was used to measure the area of the clusters and the diameter of the axonal fibers on maximum projections of the $\mathrm{Z}$ series. A scale of values and a unit of length were set, and the two channels, FITC and TRITC, were split from each projection. The area of each Nav cluster to be measured was traced two to three times by two independent investigators, visually defining the perimeter as a qualitatively reduced intensity, and then calculated and averaged. Thus, this technique does not include the area of "dispersion" with low Nav staining. The average area was normalized for the average diameter of the fiber, measured by drawing a line through Caspr staining at the border between paranode and node. The values were compared by Student's $t$ test. The quantitative analysis of the dystrophic roots was made without normalization because of the absence of Caspr clusters.

\section{Results}

\section{Laminins 2 and 10 are abundant in the basal laminas} surrounding nodes of Ranvier

A continuous basal lamina surrounds the outer surface of Schwann cells along internodes, extending over paranodes and 

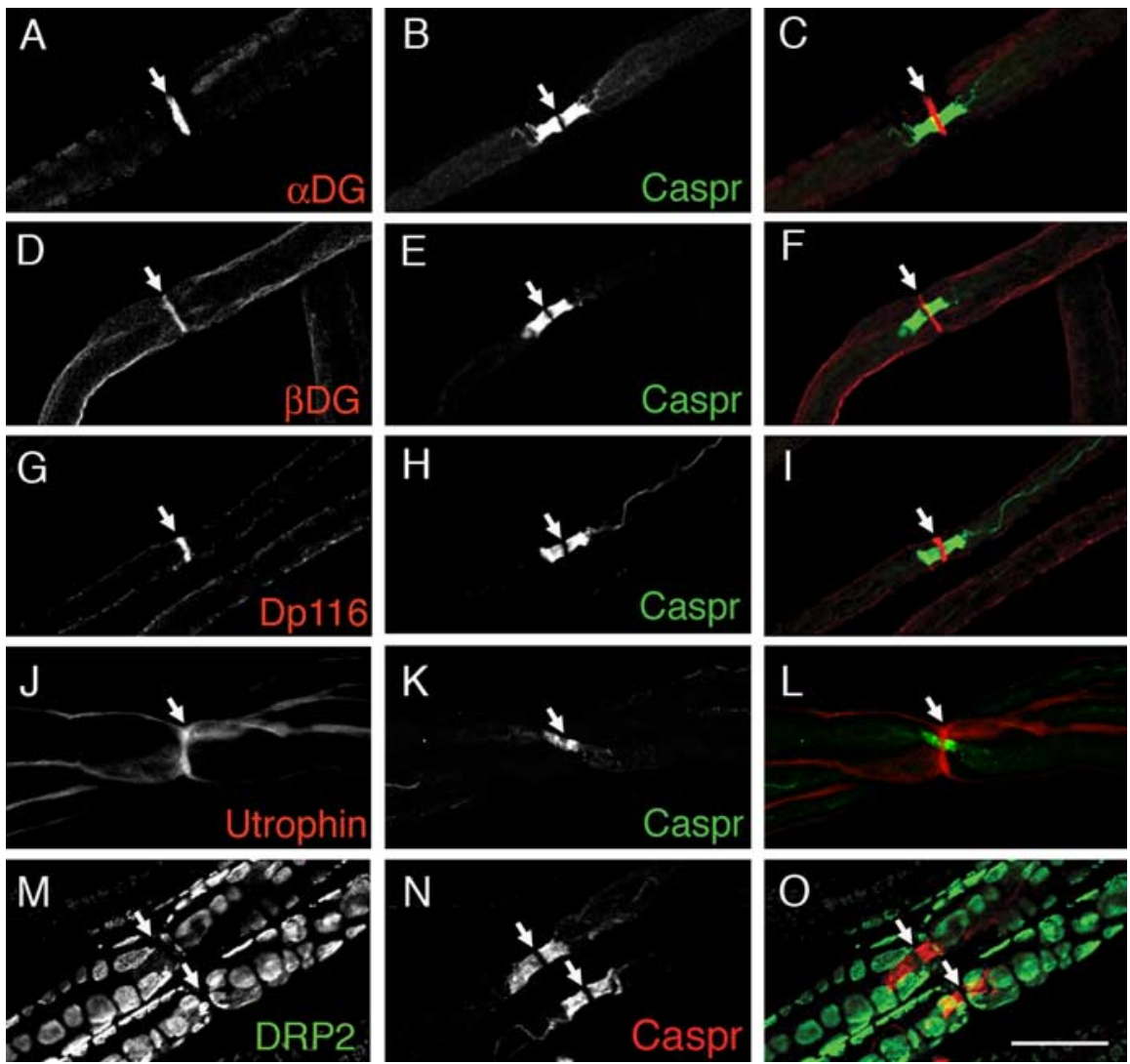

Figure 2. Specific members of the dystrophin-glycoprotein complex are present at nodes. Teased fibers of adult rat sciatic nerves stained with an antibody against the paranodal marker Caspr (green in $\boldsymbol{B}, \boldsymbol{E}, \boldsymbol{H}, \boldsymbol{K}$; red in $\boldsymbol{N}$ ). The picture shows the localization of $\alpha$-dystroglycan $(\boldsymbol{A}$, arrow) and $\beta$-dystroglycan $(\boldsymbol{D}$, arrow) at the nodes of Ranvier. The monoclonal antibody against the dystrophin isoform, Dp116, shows a striking microvillar enrichment ( $G$, arrow). Utrophin is also present at nodes ( $\boldsymbol{J}$, arrow), whereas dystrophin-related protein 2 and periaxin are absent at nodes ( $\boldsymbol{M}$; data not shown). The merged confocal images are shown at the right $(\boldsymbol{C}, \boldsymbol{F}, \boldsymbol{I}, \boldsymbol{L}, \mathbf{0})$. DG, Dystroglycan. Scale bar, $16 \mu \mathrm{m}$.

nodes to adjacent internodes. To determine whether laminins were present in the basal lamina above nodes, and whether their isoform composition was similar to that of internodes, we stained teased fibers from mouse sciatic nerves using antibodies to $\alpha 1$, $\alpha 2, \alpha 4, \alpha 5, \beta 2$, and $\gamma 1$ laminin chains (Table 2). Laminin chains $\alpha 2, \alpha 5$, and $\gamma 1$ were abundant at nodes (Fig. $1 A-I$ ), whereas $\alpha 1$ and $\beta 2$ chains were absent (Fig. 1) (data not shown). Laminin $\alpha 4$ chain, which is expressed at low levels in adult nerves (Sanes et al., 1990; Patton et al., 1997; Previtali et al., 2003), was also weakly detected at nodes (data not shown). Thus, laminin 2, the major isoform of mature nerves, is highly abundant over microvilli at nodes. Laminin $\alpha 5$ was absent from internodes (Fig. $1 D$, arrowhead) (Patton et al., 1997) but was localized in the basal lamina around nodes and paranodes, as shown by colocalization with the paranodal marker Caspr (Fig. $1 D-F$ ). Because the $\beta 2$ laminin chain is absent from nodes (data not shown) but the $\beta 1$ chain is present in mature nerves, laminin 10 should be the isoform present at nodes. These data agree with those reported recently in abstract form (Vagnerova et al., 2003). In cross sections, laminins were present as a ring external to ezrin radixin moesin (ERM)-positive microvilli but were never found between microvilli and the axon (data not shown). Finally, in dystrophic $d y^{2 J} / d y^{2 J}$ mice, which have nonfunctional laminin 2 because of a mutation in the $\alpha 2$ chain (Sunada et al., 1995; Colognato et al., 1999), $\alpha 1$ laminin chain expression was upregulated at nodes (Fig. $1 \mathrm{I}$ ), as shown previously for internodes (Previtali et al., 2003). The increase in $\alpha 1$ laminin was documented previously by semiquantitative RT-PCR and Western blots (Previtali et al., 2003).

\section{A specific dystrophin-glycoprotein complex at nodes}

Having shown that specific laminins are present at nodes of Ranvier, we asked which members of the dystrophin-glycoprotein complex were present at nodes in rat and mouse nerves. In internodes, dystroglycan forms a complex with specific isoforms of dystrophin: Dp116 and DRP2, as well as with periaxin, utrophin, and sarcoglycans (Byers et al., 1993; Saito et al., 1999; Sherman et al., 2001). Figure 2 shows that $\alpha$ and $\beta$ dystroglycan, Dp116, and utrophin were present at nodes of Ranvier, whereas DRP2 and periaxin were not (Fig. 2 and data not shown). In particular, Dp116 appeared strikingly localized to microvilli (Fig. $2 G-I)$. These data show that the repertoire of dystroglycan-dystrophin linkage at nodes of Ranvier differs from that along internodes.

\section{Dystrophic $d y^{2 J} / d y^{2 J}$ mice have minor myelin abnormalities in} peripheral nerves, but reduced nerve conduction velocity

To explore whether dystroglycan alterations at nodes of Ranvier represent a loss of laminin receptor function, we compared the phenotypes of dystroglycan-null mice and $d y^{2 J} / d y^{2 J}$ mice. Older studies showed that dystrophic mice have reduced nerve conduction velocity (Rasminsky et al., 1978) and widened nodes of Ranvier (Bradley et al., 1977; Jaros and Bradley, 1979; Jaros and Jenkison, 1983). These studies were performed on $d y / d y$ mice, which lack laminin 2 because of an unidentified genetic defect mapping to the laminin $\alpha 2$ locus (Sunada et al., 1994). To compare the phenotype of laminin 2 mutants to that of dystroglycan mutants, we used $d y$ strophic $d y^{2 J} / d y^{2 J}$ mice instead, which have nonfunctional laminin 2 because of a known mutation in the $\alpha 2$ chain. First, we validated the model by showing that, similarly to $d y / d y$ mice, $d y$ strophic $d y^{2 J} / d y^{2 J}$ mice have a $30 \%$ reduction in nerve conduction velocity and an increased $F$-wave latency (Fig. 3). Dystrophic $d y / d y$ and $d y^{2 J} / d y^{2 J}$ mice have defective radial sorting of axons that results in bundles of naked axons, more severe in spinal roots than in distal nerves (Bradley and Jenkison, 1973). To evaluate the potential contribution of the distal sorting defects to the observed reduction in nerve conduction velocity, we compared semithin sections of roots and sciatic nerves in $d y^{2 J} / d y^{2 J}$ mice. As shown in Figure 3, the radial sorting defect was much more pronounced in roots than in distal nerves (Fig. 3) (Bradley and Jenkison, 1975; Weinberg et al., 1975). Thus, axonal sorting defects in nerves do not likely explain the observed reduction in nerve conduction velocity in the nerves themselves. Therefore, mice lacking laminin 2 phenocopy the slowing in nerve conduction velocity seen in mice lacking Schwann cell dystroglycan (Saito et al., 2003). 


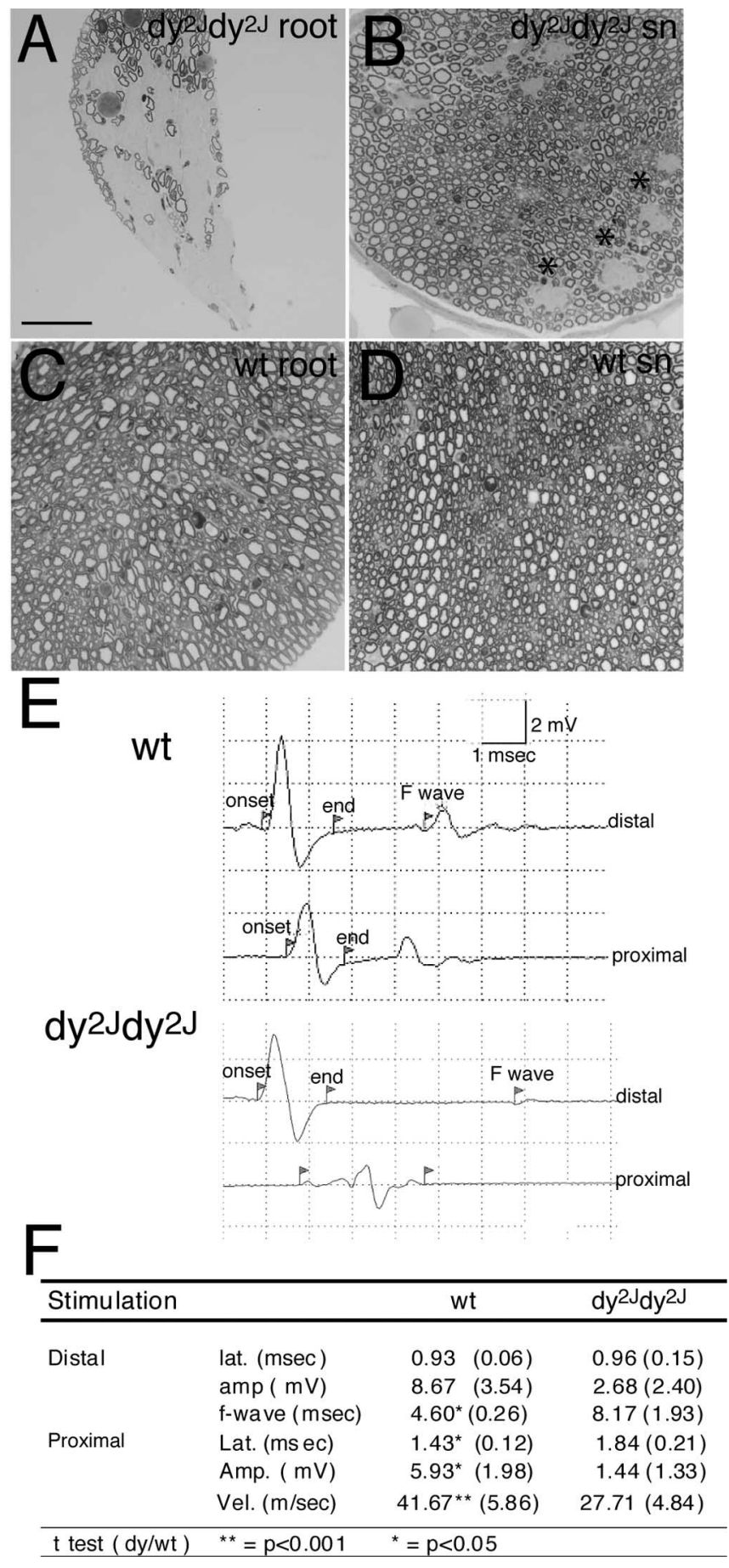

Figure 3. Proximal defects in radial sorting and reduced nerve conduction velocity in peripheral nerves of $d y s t r o p h i c ~ d y^{2 J} d y^{2 J}$ mice. Semithin cross sections of spinal roots $(\boldsymbol{A})$ and sciatic nerve $(\boldsymbol{B})$ from adult $d y^{2 J} d y^{2 J}$ mice and wild-type mice ( $\boldsymbol{C}, \boldsymbol{D}$, respectively). Defect in radial sorting is prevalent in spinal roots of dystrophic mice, whereas in sciatic nerves few bundles of amyelinated axons are present ( $\boldsymbol{B}$, asterisks). Scale bar, $80 \mu \mathrm{m}$. $\boldsymbol{E}$, Traces show the control and dystrophic profiles of compound motor action potentials recorded after stimulation at the ankle (distal) and at the sciatic notch (proximal). The onset and end of the compound motor action potential and the onset of the $F$-wave are indicated by flags. $\boldsymbol{F}$, The table shows an increase in the $F$-wave latency and a decrease in nerve conduction velocity in dystrophic peripheral nerves $(n=7)$ compared with wild type $(n=3)$. SDs are indicated in parentheses. sn, Sciatic nerve.

\section{Dystrophic $d y^{2 J} / d y^{2 J}$ mice have abnormal nodes of Ranvier and microvilli}

To study microvilli in $d y^{2 J} / d y^{2 J}$ mice, we examined the ultrastructure of nodes in longitudinal sections of sciatic nerves from $d y^{2 J} /$ $d y^{2 J}$ mice and control nerves. As shown in Figure 4, some nodes in dystrophic nerves were abnormally wide $(>5 \mu \mathrm{m})$, with poorly formed microvilli. These abnormalities were present at various degrees in $\sim 20 \%$ of nodes. In extreme cases, microvilli were absent, such as the node shown in Figure $4 \mathrm{~A}$.

Next, we determined whether the molecular components of the nodal region were altered in $d y^{2 J} / d y^{2 J}$. Staining with microvilli markers showed normal staining for Dp116 in $d y^{2 I} / d y^{2 J}$ mice (Fig. 4) as well as for radixin, moesin, and ezrin (Scherer et al., 2001) in the majority of $d y^{2 J} / d y^{2 J}$ and dystroglycan-null nodes (Fig. 4 and data not shown). ERM protein phosphorylation, as determined by staining with a phosphospecific antibody, appeared normal in many nodes, but was reduced or absent in some nodes of both dystrophic and dystroglycan-null nerves (Fig. 4) (data not shown). To analyze the localization of paranodal and juxtaparanodal molecules in $d y^{2 J} / d y^{2 J}$ mice, we stained teased sciatic nerve fibers with antibodies recognizing paranodal (Caspr on axons and Neurofascin 155 on Schwann cells) and juxtaparanodal (Kv1.1 potassium channels) markers. Supplemental Figure 1 (available at www.jneurosci.org as supplemental material) shows that, similarly to mice lacking Schwann cell dystroglycan, glial and axonal paranodal and juxtaparanodal markers are correctly localized in $d y^{2 J} / d y^{2 J}$ nerves. Thus, nodes lacking functional laminin 2 have various degrees of abnormalities that phenocopy those seen in mice lacking Schwann cell dystroglycan.

\section{Dystrophic $d y^{2 J} / d y^{2 J}$ mice have abnormal Nav channel clusters}

To determine whether Nav clusters were also perturbed in $d y^{2 J} /$ $d y^{2 J}$ mice, we compared Nav staining on teased sciatic nerves from $d y^{2 J} / d y^{2 J}$ mice to that in control nerves and in nerves lacking Schwann cell dystroglycan. Antibodies directed against all Nav isoforms, or to Nav1.6, the major isoform present at mature nodes (Boiko et al., 2001), were used. In nerves from $d y^{2 J} / d y^{2 J}$ animals, Nav clusters were often smaller, stained with lower intensity, and were more irregularly shaped than those of control animals. Whereas clusters in wild-type animals were rectangular and had square corners, $d y^{2 J} / d y^{2 J}$ clusters were irregular and lacked definite corners (Fig. 5, compare $A$ with $G$ and $I-K$ with $R-T)$. Some clusters were dispersed laterally (Fig. 5I). Because paranodal junctions were normal (data not shown) it is possible that laterally diffused clusters are present in abnormally wide nodes of Ranvier. "Binary nodes," two distinct Nav clusters on the same axon separated by space, were rarely seen. These abnormalities were identical in quality but less severe than those observed in nerves lacking dystroglycan (Saito et al., 2003), in which the low intensity and lateral dispersion of Nav were more extreme (Fig. $5 C, L-N$ ). Such abnormal clusters may occasionally be observed in control nerves because of the handling of fibers during teasing, but, when counted blindly, abnormal clusters were significantly more frequent in mutant than in control mice $33 \%$ of dystrophic and $58 \%$ of dystroglycan-null nodes; $p=0.001$ in both, when compared with their own control by $\chi^{2}$ test) (Fig. $5 U)$. Thus, Nav channels are abnormally clustered, with an apparent lower density, in mice lacking laminin 2 as in mice with dystroglycan-null Schwann cells. Similarly to dystroglycan-null and control nerves, the immature $1.2 \mathrm{Nav}$ isoform was only occasionally found in dystrophic nodes (Saito et al., 2003) (supplemental Fig. 2, available at www.jneurosci.org).

\section{Nerves of mice lacking all Schwann cell laminins have widespread nodal abnormalities}

The above data show that nodal abnormalities were more severe in mice lacking dystroglycan than in mice lacking laminin 2. To 


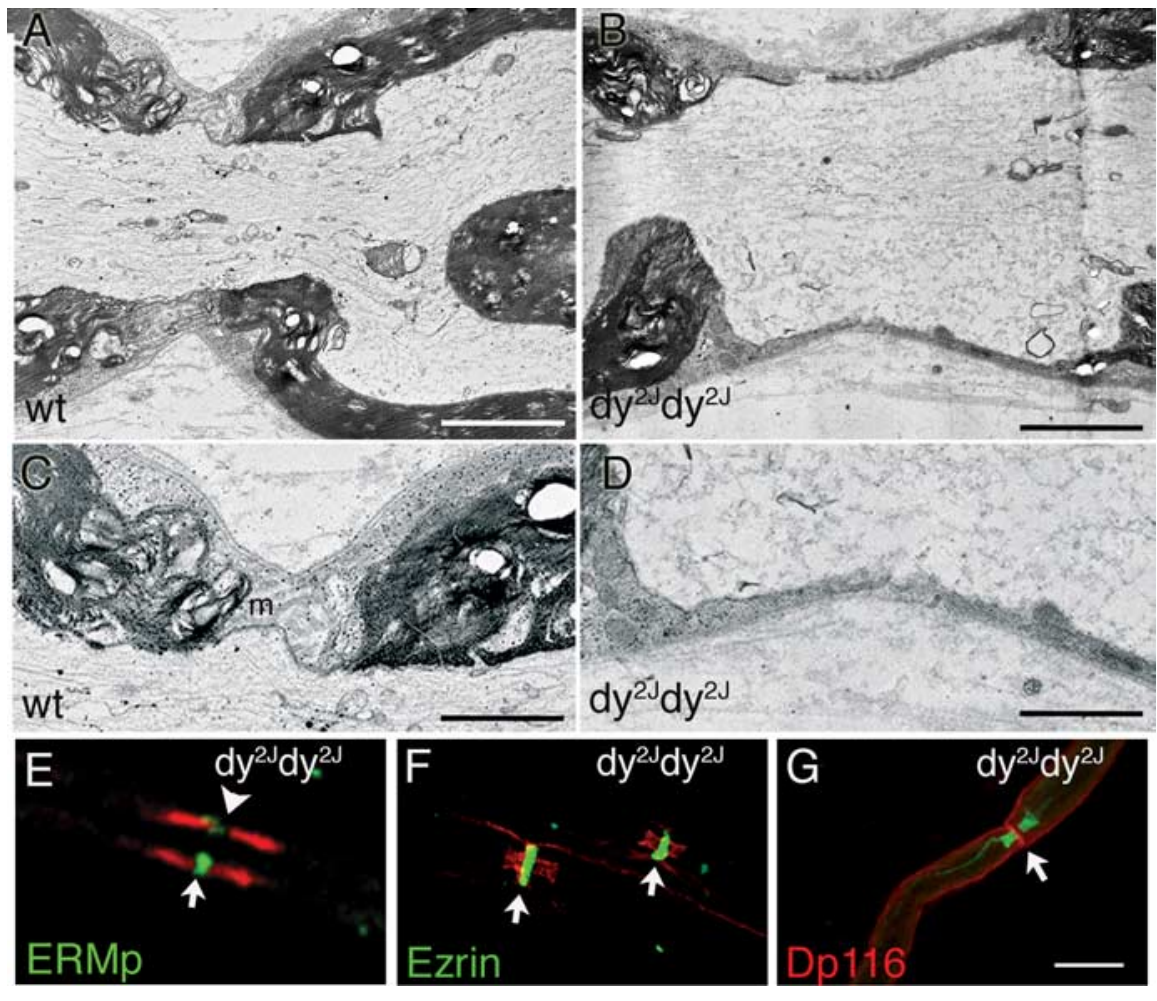

Figure 4. Ultrastructural abnormalities in microvilli and the nodal region of dystrophic $d y^{2 J} d y^{2 J}$ mice. Electron micrographs of longitudinal sections of mouse sciatic nerves show increased width of some nodes in dystrophic mice $(\boldsymbol{B}, \boldsymbol{D})$. Microvilli (m in wt) are hypotrophic in dystrophic nodes $(\boldsymbol{D}$, enlargement from $\boldsymbol{B}) . \boldsymbol{E}-\boldsymbol{G}$, Immunofluorescent analysis of dystrophic teased fibers from adult sciatic nerves double stained with Caspr $(\boldsymbol{E}, \boldsymbol{F}$, mouse monoclonal in red; $\boldsymbol{G}$, rabbit antiserum in green) and microvilli markers. The ERM proteins ezrin ( $\boldsymbol{F}$, arrows) and radixin (data not shown) and the dystrophin isoform Dp116 ( $G$, arrow) are correctly concentrated in most Schwann cell microvilli. The phosphorylation of ERM proteins, as determined by staining with a phosphospecific antibody ( $\boldsymbol{E}$, arrow), appears normal in some dystrophic nodes and reduced in others ( $\boldsymbol{E}$, arrowhead). Scale bars: $\boldsymbol{A}, \boldsymbol{B}, 2 \mu \mathrm{m} ; \boldsymbol{C}, \boldsymbol{D}$, $1 \mu \mathrm{m} ; \boldsymbol{E}-\mathbf{G}, 16 \mu \mathrm{m}$. ERMp, Phosphorylated ERM.

evaluate whether this was attributable to redundant/compensatory function of other laminins present at nodes of Ranvier of dystrophic mice (laminin 1 and laminin 10), we studied Nav clustering in mice in which the laminin $\gamma 1$ chain gene, common to all of the laminin isoforms present in Schwann cells, was specifically ablated in Schwann cells using the Cre/loxP system (P0Cre $\gamma 1$ null). In these nerves, most axons are naked because of defective radial sorting (Yu et al., 2005). In the few myelinated fibers, recognizable by paranodal Caspr staining, Nav clusters presented the same abnormalities described in dystrophic mice, but more severe (Fig. 5E, O-Q) and at higher frequency (59\% of abnormal clusters; $p=0.001$ by $\chi^{2}$ test when compared with controls). Thus, compensation by laminin 1 and/or redundancy with laminin 10 (Yang et al., 2005) probably partially substitute for the lack of laminin 2 in dystrophic nodes.

\section{Severe Nav cluster abnormalities are present in roots of $d y^{2 J} / d y^{2 J}$ mice}

The presence of Nav clusters in naked axons of dystrophic mice roots have been reported (Deerinck et al., 1997) and cited as evidence that microvilli and glial contact are not strictly necessary for Nav clustering. Having classified normal and abnormal Nav clusters in mutant dystrophic and dystroglycan mice, we asked whether clusters on dystrophic roots were normal. Dystrophic roots contained naked axons and myelinated fibers (Fig. 3), distinguishable by the absence or presence of Caspr paranodal staining, respectively. Indeed, Nav clusters could be seen in amyeli- nated areas, but they were extremely small, faintly stained, and irregularly shaped or diffuse (Fig. 6). Comparison between naked and myelinated axons showed that the abnormalities were clearly most severe in amyelinated axons (Fig. 6). Microvilli were absent at these sites, as shown by lack of radixin staining (Fig. 6). Thus, in the absence of glial processes, Nav clusters are recognizable, but highly abnormal.

The area and density of Nav clusters are reduced in the absence of laminins and dystroglycan

So far, we presented evidence that $\mathrm{Nav}$ clusters are qualitatively abnormal when Schwann cells lack laminins or dystroglycan, and these abnormalities correlate with abnormalities in microvilli at nodes of Ranvier. Furthermore, when microvilli are completely missing, Nav clusters appear most abnormal. To quantify these differences, we measured the size of $\mathrm{Nav}$ clusters, stained with anti-Nav antibodies, in nerves from mice lacking laminin 2 $\left(d y^{2 J} / d y^{2 J}\right)$, all laminins (P0Cre $\left.\gamma 1\right)$ or dystroglycan (P0Cre DG), and in naked roots lacking microvilli completely $\left(d y^{2 J} / d y^{2 J}\right)$. As shown in Figure 7, the area occupied by Nav clusters was similarly reduced in mice lacking laminins or dystroglycan, and more severely reduced in naked axons from dystrophic roots. Thus, the severity in reduction of Nav clusters area correlates with the severity of microvilli abnormalities. Reduction of the area of Nav clusters was not attributable to a reduction in fiber diameters in mutant nerves, because it remained smaller than in control nerves when corrected for fiber diameter (as estimated by Caspr staining) (Fig. 7).

\section{Abnormal Nav clusters in a MDC1A patient}

$d y^{2 J} / d y^{2 J}$ mice are a model for MDC1A. MDC1A patients are heterogeneous, but most have reduced nerve conduction velocities (Shorer et al., 1995; Quijano-Roy et al., 2004). To determine whether abnormalities in Nav clustering can account for slowing of conduction velocity, we evaluated an MDC1A patient with a Gly600Arg mutation in the LAMA2 gene, in which a peripheral neuropathy with slow nerve conduction has been described previously (Di Muzio et al., 2003). Double staining of frozen sections from the sural biopsy of the MDC1A patient with anti-Nav and anti-Caspr antibodies showed abnormalities in Nav clusters (12 of 18 abnormal nodes), when compared with those of a patient with an unrelated inflammatory neuropathy (7 of 23 abnormal nodes) ( $p<0.02$ by $\chi^{2}$ test) (Fig. 8 ). Thus, the laminin 2 deficit in humans causes Nav clustering abnormalities similar to those observed in mouse models lacking laminins or dystroglycan. These abnormalities likely contribute to the observed reduction in nerve conduction velocity.

\section{Discussion}

In this paper, we show that the node of Ranvier contains a specific repertoire of laminins and dystrophin linkages to the cytoskele- 
ton. Thus, the discrete microdomains of myelinated axons also extend to the external Schwann cell surface. In addition, we show that eliminating one or more components of these outer surface microdomains is sufficient to cause nodal abnormalities, including abnormal microvilli and abnormal clusters of Nav, which likely contribute to reduced conduction velocities in mice and in MDC1A patients.

\section{Specific laminins and specific} dystrophin-glycoprotein complexes at nodes

Myelinated axons and the overlying Schwann cells are longitudinally polarized in corresponding domains (Poliak and Peles, 2003; Salzer, 2003). We find that the basal lamina, a continuous structure outside the Schwann cells (as is the axon inside), is also longitudinally polarized, because the nodal-paranodal-juxtaparanodal region has a different laminin composition than the rest of the internode. In addition, this regional difference appears to be accompanied by a different cytoskeletal linkage through different dystroglycan complexes. This resembles the situation in muscle fibers and in other tissues, in which laminin, laminin receptors, and cytoskeletal components are organized in discrete domains, influencing cell polarization and tissue morphogenesis (for review, see Yurchenco et al., 2004). Thus, the entire basal lamina/Schwann cell/axon unit is polarized, and laminins may play an essential role in the polarization and morphogenesis of the peripheral nerve unit.

\section{Laminins cooperate with dystroglycan at nodes}

We find that the nodal abnormalities of laminin-deficient Schwann cells resemble those of dystroglycan-deficient Schwann cells. In the absence of laminin 2, Schwann cells have poorly formed and misoriented microvilli, altered Nav clustering that is qualitatively similar to dystroglycan-null Schwann cells, and normal paranodes and juxtaparanodes. The quantitative differences in severity between the two mutants can be explained by redundancy with laminin 10 or compensation by laminin 1 in dystrophic mice. That the phenotypes overlap at the node of Ranvier strongly suggests that laminins and dystroglycan are in the same genetic pathway that promotes nodal Nav clustering. Because laminin is a ligand for dystroglycan in Schwann cells (Yamada et al., 1996), it is plausible that there is an epistatic relationship between them.

Laminins and dystroglycan could promote Nav clustering in two, non-mutually exclusive, ways. First, the binding of dystroglycan to laminin transmits signals that organize the cytoskeleton of microvilli, contributing to mechanisms that form or constrain Nav clusters. This interaction need not occur only at nodes, and could maintain proper orientation of microvilli toward the axon so that molecules on microvilli tips, such as gliomedin, would be allowed to bind the NrCAM/Neurofascin 186/Nav complex. This is a conservative interpretation of our data and fits with the recent finding that dystroglycan regulates the actin cytoskeleton
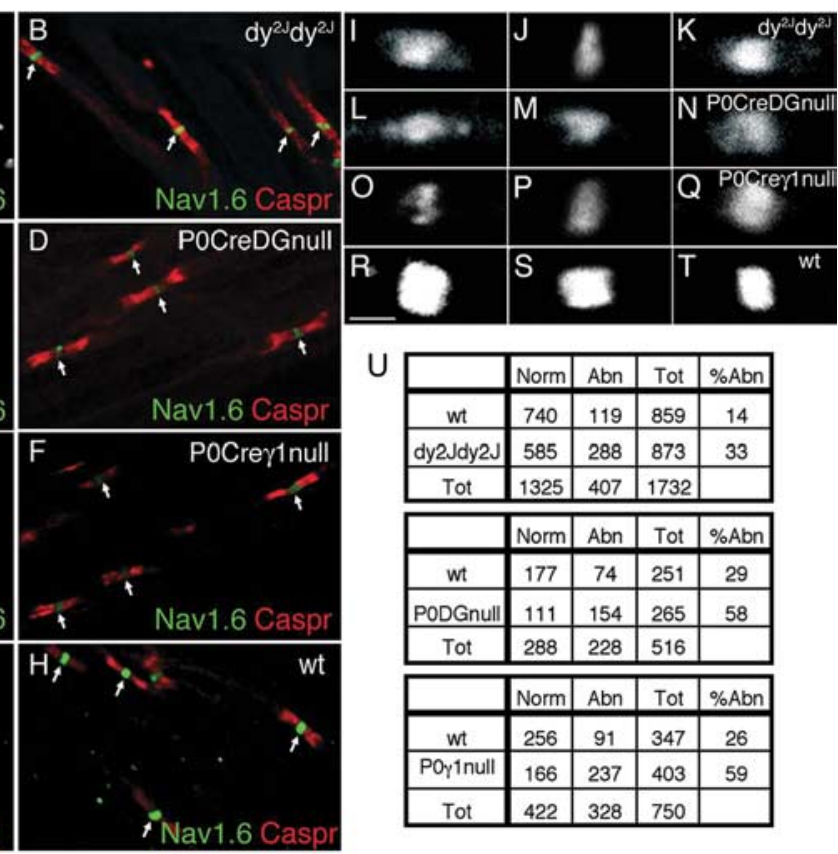

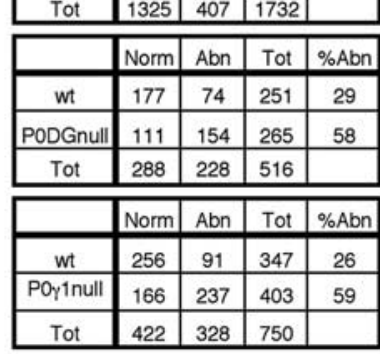

Tot
\begin{tabular}{|c|c|c|c|c|}
\hline & 288 & 228 & 516 & \\
\hline Norm & Abn & Tot & $\%$ Abn \\
\hline wt & 256 & 91 & 347 & 26 \\
\hline P0y1null & 166 & 237 & 403 & 59 \\
\hline Tot & 422 & 328 & 750 & \\
\hline
\end{tabular}

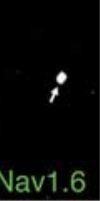

Figure 5. Abnormality in Nav clusters in the absence of laminins or dystroglycan. Immunofluorescence microscopy of teased those of typical dystroglycan and laminin $\gamma 1$-null nodes (enlarged in $\boldsymbol{L}-\boldsymbol{N}$ and $\mathbf{0}-\boldsymbol{Q}$, respectively). $\boldsymbol{U}$, Ouantification of frequency

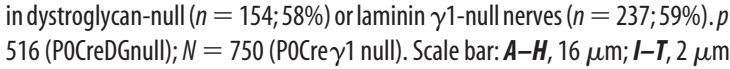

through ezrin (Spence et al., 2004). However, at least at the level of immunohistochemistry, ERM, ERM phosphorylation, and Dp116 were not severely disrupted in mutant mice.

Second, dystroglycan could have a more direct role in microvilli, distinct from laminin binding, by binding other microvillar or axonal components of the node. Gliomedin has been shown recently to bind the NrCAM/Neurofascin 186/Nav complex and to enucleate Nav clusters on cultured DRG axons (Eshed et al., 2005). Gliomedin contains a collagen motif that could interact with molecules such as dystroglycan on microvilli (Eshed et al., 2005). Alternatively, Schwann cell dystroglycan can bind agrin (Yamada et al., 1996), and in other cell types dystroglycan can bind perlecan, biglycan, and neurexin (Talts et al., 1999; Bowe et al., 2000; Sugita et al., 2001). The role of non-neuronal agrin in peripheral nerve is unknown, but Schwann cells contain active agrin isoforms with acetylcholine receptor clusterizing activity (Yang et al., 2001). Thus, dystroglycan could immobilize diffusible agrin in a proteoglycan complex to facilitate Nav clustering, as it happens for acetylcholine receptors at neuromuscular junctions (Grady et al., 2000; Jacobson et al., 2001). In these interpretations, laminin would bind a different receptor over nodes (e.g., $\alpha 6 \beta 1$ integrin), and dystroglycan would have a different binding partner (e.g., agrin, proteoglycans, Neurofascin 186) and more directly cluster or bind Nav on the axonal membrane.

Laminins and their actin linkage may participate in the formation of barriers or molecular sieves at the node

The formation of the axoglial apparatus at nodes of Ranvier probably depends on a temporal hierarchy of sorting, targeting, as- 

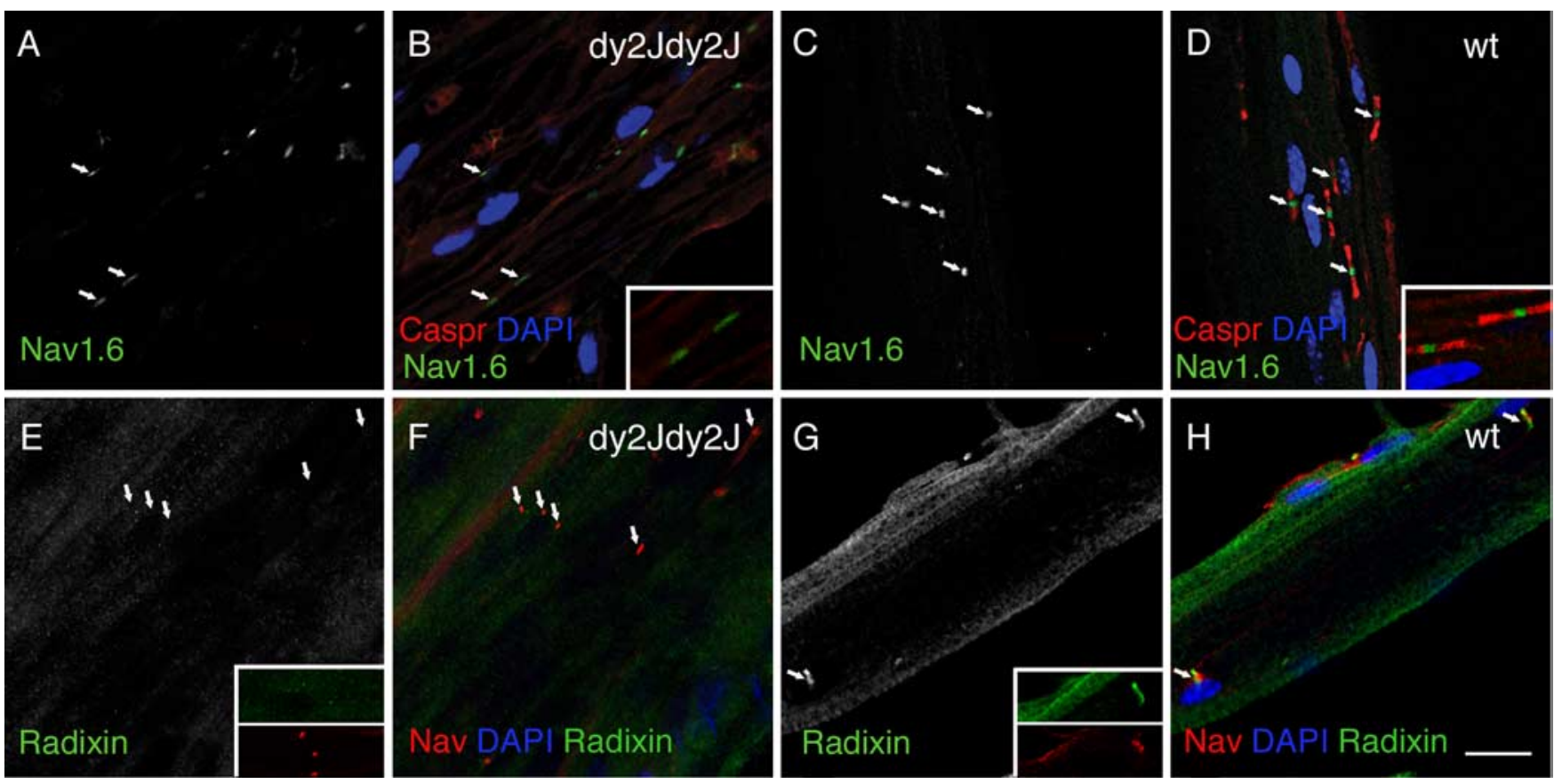

Figure 6. Severe abnormalities of Nav clusters in naked axons of dystrophic roots. Confocal images of Nav clusters in dystrophic $(\boldsymbol{A}, \boldsymbol{B}, \boldsymbol{E}, \boldsymbol{F})$ and normal $(\boldsymbol{C}, \boldsymbol{D}, \boldsymbol{G}, \boldsymbol{H})$ teased spinal roots immunolabeled with anti-Nav1.6 (green) and anti-Caspr (red) antibodies in $\boldsymbol{A}-\boldsymbol{D}$, or anti-radixin (green) and anti-panNav (red) in $\boldsymbol{E}-\boldsymbol{H}$. Faint Nav immunoreactivity is present at discrete sites along dystrophic fibers ( $\boldsymbol{A}$, arrows and enlargement), likely corresponding to naked axons because of a lack of the paranodal Caspr (red) and nuclear $4^{\prime}, 6^{\prime}$-diamidino-2-phenylindole (DAPI) (blue) markers $(\boldsymbol{B})$. Nav clusters found in these regions are small, irregularly shaped, and diffusive along the fiber $(\boldsymbol{A}, \boldsymbol{B}$, arrows), compared with Nav clusters from wild-type spinal roots $(\boldsymbol{C}, \boldsymbol{D})$. These clusters form in the absence of microvilli, as shown by the lack of radixin staining ( $\boldsymbol{E}, \boldsymbol{F}$, and enlargements). Scale bar, $16 \mu \mathrm{m}$.

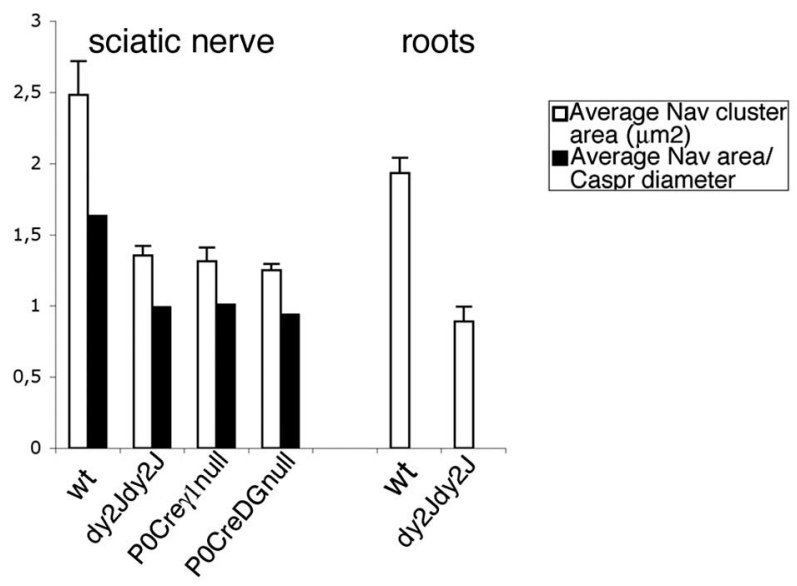

\begin{tabular}{|l|l|l|l|}
\hline genotype & $\begin{array}{l}\text { Average Nav cluster } \\
\text { area }\end{array}$ & $\begin{array}{l}\text { Average } \\
\text { diameter }\end{array}$ & $\begin{array}{l}\text { Student test } \\
\text { mutant/wt }\end{array}$ \\
\hline wild type $(\mathrm{n}=23)$ & 2.480 & 1.521 & \\
\hline$d y^{2 J} / d y^{2 J}(\mathrm{n}=50)$ & 1.354 & 1.366 & $\mathrm{p}<0.001$ \\
\hline P0Cre $\gamma^{1}(\mathrm{n}=21)$ & 1.313 & 1.297 & $\mathrm{p}<0.0005$ \\
\hline P0Cre DG $(\mathrm{n}=56)$ & 1.249 & 1.316 & $\mathrm{p}<0.0001$ \\
\hline wild type roots $(\mathrm{n}=63)$ & 1.932 & & \\
\hline$d y^{2 J} / d y^{2 J}$ roots $(\mathrm{n}=45)$ & 0.891 & & $\mathrm{p}<0.0001$ \\
\hline
\end{tabular}

Figure 7. Decrease in the area of Nav channel clusters in the absence of laminins or dystroglycan. Quantitative analysis of the area occupied by Nav clusters in nodes from dystrophic, laminin $\gamma 1$-null, and dystroglycan-null sciatic nerves and dystrophic roots. Open columns represent the average areas stained with anti-Nav1.6 antibodies. Filled columns show the same data after normalization for fiber diameter. A reduction in the area of Nav clusters is evident in dystrophic $d y^{2 J} d y^{2 J}$, laminin $\gamma 1$, and dystroglycan-null sciatic nerves compared with controls. Similar quantitative analysis in dystrophic roots shows a severe reduction in the area of $\mathrm{Nav}$ clusters compared with wild-type roots.

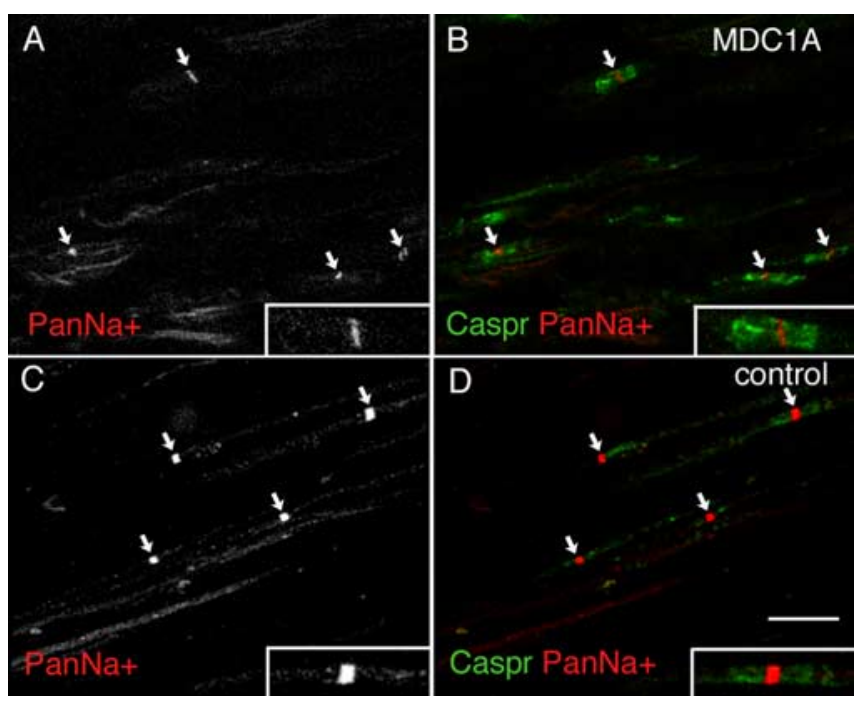

Figure 8. Nav clusters abnormalities in an MDC1A patient. Longitudinal sections of sural nerve biopsies from an $\operatorname{MDC} 1 A$ patient $(A, B)$ and a control sural nerve $(\boldsymbol{C}, \boldsymbol{D})$ double stained with an antibody that recognizes all isoforms of sodium channels $\left(\mathrm{PanNa}^{+}{ }^{+}\right.$, red) and an anti-Caspr antibody (green). $\boldsymbol{A}, \boldsymbol{B}$, The image shows a reduction in the intensity of staining for Nav clusters (arrows, enlarged in insets) on MDC1A nerves compared with control nerves. Scale bar, $16 \mu \mathrm{m}$.

sembly, and constraining mechanisms (Pedraza et al., 2001). Among the constraining mechanisms, molecular sieves or barriers have been proposed that could restrict the lateral passage of Nav, maintaining their selective localization at nodes (Rosenbluth, 1981; Vabnick et al., 1996). These sieves comprise a molecular scaffold that is linked to the cytoskeleton by transmembrane proteins, that spans both the axon and the Schwann cell, and that depends on trans interaction at the axoglial junction. Finally these molecular scaffolds could operate during develop- 
ment, by "pushing" Nav from internodes toward the node, driven by the longitudinal elongation of Schwann cells (Dugandzija-Novakovic et al., 1995; Pedraza et al., 2001). This model predicts that different domains of specific glial and axonal molecules must exist, that actin binding proteins are important in the formation of the scaffold, and that the lateral force mounted by the elongating Schwann cell during development would be crucial to properly compact Nav clusters at nodes. Strikingly, all of the data presented here fit with this model, because we show that there is a precise distribution of selective laminins and transmembrane and actin-binding proteins at the outer Schwann cell surface above the nodes of Ranvier, and that these molecules are crucial for the normal nodal architecture.

\section{Role of microvilli in Nav clustering}

We show that the most severe abnormalities in Nav clusters were present on the naked axons found in dystrophic roots and laminin $\gamma 1$-null sciatic nerves. Here, Schwann cell processes, and therefore microvilli, are completely absent. These data extend the work of Deerinck et al. (1997), who noted the presence of Nav clusters in naked dystrophic roots but did not classify them as normal or abnormal. In keeping with our analysis, the dystrophic clusters presented in Figure 1 of their paper are irregularly shaped and diffuse. Thus, we propose that, in vivo, axons alone can initiate nucleation of Nav clusters, but also that microvilli are required to catalyze and/or maintain proper clusters, akin to the prepatterning versus stable synaptic contact formation of acetylcholine receptor clusters at neuromuscular junctions (Burden, 2002). Interestingly, dystroglycan modulates this transition at neuromuscular junctions (Grady et al., 2000; Jacobson et al., 2001). It is important to note that a naked axon in a dystrophic mouse may not be devoid of Schwann cells throughout its full length, but may enter and exit from myelinated regions. Thus, any naked axon is in contact with Schwann cells at some point, and may receive instructive signals that are contact dependent, yet operate from the distance. An alternative possibility is that Schwann cell processes were present, and then retracted, around axons in bundles. This phenomena has been observed around axons of mice lacking Schwann cell $\beta 1$ integrin (Feltri et al., 2002), but not $\gamma 1$ laminin (Yu et al., 2005). In this case the role of microvilli would be not only to maintain but also to nucleate clusters. In both cases, microvilli are required for efficient formation and maintenance of Nav clusters. This function of microvilli is impaired in the absence of laminins or dystroglycan.

\section{Role of Nav clustering in the pathogenesis of congenital muscular dystrophy neuropathy}

Deficit of laminin 2 in humans and mice causes a reduction in nerve conduction velocity of $\sim 30 \%$ (Rasminsky et al., 1978; Shorer et al., 1995; Di Muzio et al., 2003). Several factors can account for this reduction, including a reported reduction of density of myelinated axons (Montgomery and Swenarchuk, 1978), as well as a reduction in internodal length (Jaros and Jenkison, 1983; Di Muzio et al., 2003; Court et al., 2004). Here, we add another potential contributor by showing that, in addition to widened nodes of Ranvier (Bradley et al., 1977; Di Muzio et al., 2003), the Nav channel density is probably reduced in both $d y^{2 J}$ / $d y^{2 J}$ and an MDC1A patient. Although it would be difficult to dissect the role of each of these factors to reduce nerve conduction velocity, all of them could contribute to the pathogenesis of the MDC1A neuropathy.

\section{References}

Boiko T, Rasband MN, Levinson SR, Caldwell JH, Mandel G, Trimmer JS, Matthews G (2001) Compact myelin dictates the differential targeting of two sodium channel isoforms in the same axon. Neuron 30:91-104.

Bowe MA, Mendis DB, Fallon JR (2000) The small leucine-rich repeat proteoglycan biglycan binds to alpha-dystroglycan and is upregulated in dystrophic muscle. J Cell Biol 148:801-810.

Bradley WG, Jenkison M (1973) Abnormalities of peripheral nerves in murine muscular dystrophy. J Neurol Sci 18:227-247.

Bradley WG, Jenkison M (1975) Neural abnormalities in the dystrophic mouse. J Neurol Sci 25:249-255.

Bradley WG, Jaros E, Jenkison M (1977) The nodes of Ranvier in the nerves of mice with muscular dystrophy. J Neuropathol Exp Neurol 36:797-806.

Burden SJ (2002) Building the vertebrate neuromuscular synapse. J Neurobiol 53:501-511.

Byers TJ, Lidov HG, Kunkel LM (1993) An alternative dystrophin transcript specific to peripheral nerve. Nat Genet 4:77-81.

Chen ZL, Strickland S (2003) Laminin gammal is critical for Schwann cell differentiation, axon myelination, and regeneration in the peripheral nerve. J Cell Biol 163:889-899.

Ching W, Zanazzi G, Levinson SR, Salzer JL (1999) Clustering of neuronal sodium channels requires contact with myelinating Schwann cells. J Neurocytol 28:295-301.

Colognato H, Winkelmann DA, Yurchenco PD (1999) Laminin polymerization induces a receptor-cytoskeleton network. J Cell Biol 145:619-631.

Court FA, Sherman DL, Pratt T, Garry EM, Ribchester RR, Cottrell DF, Fleetwood-Walker SM, Brophy PJ (2004) Restricted growth of Schwann cells lacking Cajal bands slows conduction in myelinated nerves. Nature 431:191-195.

Deerinck TJ, Levinson SR, Bennett GV, Ellisman MH (1997) Clustering of voltage-sensitive sodium channels on axons is independent of direct Schwann cell contact in the dystrophic mouse. J Neurosci 17:5080-5088.

Di Muzio A, De Angelis MV, Di Fulvio P, Ratti A, Pizzuti A, Stuppia L, Gambi D, Uncini A (2003) Dysmyelinating sensory-motor neuropathy in merosin-deficient congenital muscular dystrophy. Muscle Nerve 27:500-506.

Dugandzija-Novakovic S, Koszowski AG, Levinson SR, Shrager P (1995) Clustering of $\mathrm{Na}^{+}$channels and node of Ranvier formation in remyelinating axons. J Neurosci 15:492-503.

Ervasti JM, Campbell KP (1993) A role for the dystrophin-glycoprotein complex as a transmembrane linker between laminin and actin. J Cell Biol 122:809-823.

Eshed Y, Feinberg K, Poliak S, Sabanay H, Sarig-Nadir O, Spiegel I, Bermingham Jr JR, Peles E (2005) Gliomedin mediates Schwann cell-axon interaction and the molecular assembly of the nodes of Ranvier. Neuron 47:215-229.

Feltri ML, D'Antonio M, Quattrini A, Numerato R, Arona M, Previtali S, Chiu SY, Messing A, Wrabetz L (1999a) A novel P0 glycoprotein transgene activates expression of lacZ in myelin-forming Schwann cells. Eur J Neurosci 11:1577-1586.

Feltri ML, D'Antonio M, Previtali S, Fasolini M, Messing A, Wrabetz L (1999b) P0-Cre transgenic mice for inactivation of adhesion molecules in Schwann cells. Ann NY Acad Sci 883:116-123.

Feltri ML, Graus Porta D, Previtali SC, Nodari A, Migliavacca B, Cassetti A, Littlewood-Evans A, Reichardt LF, Messing A, Quattrini A, Mueller U, Wrabetz L (2002) Conditional disruption of beta 1 integrin in Schwann cells impedes interactions with axons. J Cell Biol 156:199-209.

Gatto CL, Walker BJ, Lambert S (2003) Local ERM activation and dynamic growth cones at Schwann cell tips implicated in efficient formation of nodes of Ranvier. J Cell Biol 162:489-498.

Grady RM, Zhou H, Cunningham JM, Henry MD, Campbell KP, Sanes JR (2000) Maturation and maintenance of the neuromuscular synapse: genetic evidence for roles of the dystrophin-glycoprotein complex. Neuron 25:279-293.

Jacobson C, Cote PD, Rossi SG, Rotundo RL, Carbonetto S (2001) The dystroglycan complex is necessary for stabilization of acetylcholine receptor clusters at neuromuscular junctions and formation of the synaptic basement membrane. J Cell Biol 152:435-450.

Jaros E, Bradley WG (1979) Atypical axon-Schwann cell relationships in the common peroneal nerve of the dystrophic mouse: an ultrastructural study. Neuropathol Appl Neurobiol 5:133-147.

Jaros E, Jenkison M (1983) Quantitative studies of the abnormal axon- 
Schwann cell relationship in the peripheral motor and sensory nerves of the dystrophic mouse. Brain Res 258:181-196.

Lambert S, Davis JQ, Bennett V (1997) Morphogenesis of the node of Ranvier: co-clusters of ankyrin and ankyrin-binding integral proteins define early developmental intermediates. J Neurosci 17:7025-7036.

Lustig M, Zanazzi G, Sakurai T, Blanco C, Levinson SR, Lambert S, Grumet M, Salzer JL (2001) Nr-CAM and neurofascin interactions regulate ankyrin $\mathrm{G}$ and sodium channel clustering at the node of Ranvier. Curr Biol 11:1864-1869.

Melendez-Vasquez CV, Rios JC, Zanazzi G, Lambert S, Bretscher A, Salzer JL (2001) Nodes of Ranvier form in association with ezrin-radixin-moesin (ERM)-positive Schwann cell processes. Proc Natl Acad Sci USA 98:1235-1240.

Montgomery A, Swenarchuk L (1978) Further observations on myelinated axon numbers in normal and dystrophic mice. J Neurol Sci 38:77-82.

Moore SA, Saito F, Chen J, Michele DE, Henry MD, Messing A, Cohn RD, Ross-Barta SE, Westra S, Williamson RA, Hoshi T, Campbell KP (2002) Deletion of brain dystroglycan recapitulates aspects of congenital muscular dystrophy. Nature 418:422-425.

Patton BL, Miner JH, Chiu AY, Sanes JR (1997) Distribution and function of laminins in the neuromuscular system of developing, adult, and mutant mice. J Cell Biol 139:1507-1521.

Pedraza L, Huang JK, Colman DR (2001) Organizing principles of the axoglial apparatus. Neuron 30:335-344.

Poliak S, Peles E (2003) The local differentiation of myelinated axons at nodes of Ranvier. Nat Rev Neurosci 4:968-980.

Previtali SC, Nodari A, Taveggia C, Pardini C, Dina G, Villa A, Wrabetz L, Quattrini A, Feltri ML (2003) Expression of laminin receptors in Schwann cell differentiation: evidence for distinct roles. J Neurosci 23:5520-5530.

Quattrini A, Previtali S, Feltri ML, Canal N, Nemni R, Wrabetz L (1996) $\beta 4$ integrin and other Schwann cell markers in axonal neuropathy. Glia 17:294-306.

Quijano-Roy S, Renault F, Romero N, Guicheney P, Fardeau M, Estournet B (2004) EMG and nerve conduction studies in children with congenital muscular dystrophy. Muscle Nerve 29:292-299.

Rasminsky M, Kearney RE, Aguayo AJ, Bray GM (1978) Conduction of nervous impulses in spinal roots and peripheral nerves of dystrophic mice. Brain Res 143:71-85.

Rosenbluth J (1981) Freeze-fracture approaches to ionophore localization in normal and myelin-deficient nerves. Adv Neurol 31:391-418.

Saito F, Masaki T, Kamakura K, Anderson LV, Fujita S, Fukuta-Ohi H, Sunada Y, Shimizu T, Matsumura K (1999) Characterization of the transmembrane molecular architecture of the dystroglycan complex in Schwann cells. J Biol Chem 274:8240-8246.

Saito F, Moore SA, Barresi R, Henry MD, Messing A, Ross-Barta SE, Cohn RD, Williamson RA, Sluka KA, Sherman DL, Brophy PJ, Schmelzer JD, Low PA, Wrabetz L, Feltri ML, Campbell KP (2003) Unique role of dystroglycan in peripheral nerve myelination, nodal structure, and sodium channel stabilization. Neuron 38:747-758.

Salzer JL (2003) Polarized domains of myelinated axons. Neuron 40:297-318.

Sanes JR, Engvall E, Butkowski R, Hunter DD (1990) Molecular heterogeneity of basal laminae: isoforms of laminin and collagen IV at the neuromuscular junction and elsewhere. J Cell Biol 111:1685-1699.

Scherer SS, Xu T, Crino P, Arroyo EJ, Gutmann DH (2001) Ezrin, radixin, and moesin are components of Schwann cell microvilli. J Neurosci Res 65:150-164.
Scherer SS, Arroyo E, Peles E (2004) Functional organization of the nodes of Ranvier. San Diego: Elsevier.

Sherman DL, Fabrizi C, Gillespie CS, Brophy PJ (2001) Specific disruption of a Schwann cell dystrophin-related protein complex in a demyelinating neuropathy. Neuron 30:677-687.

Shorer Z, Philpot J, Muntoni F, Sewry C, Dubowitz V (1995) Demyelinating peripheral neuropathy in merosin-deficient congenital muscular dystrophy. J Child Neurol 10:472-475.

Spence HJ, Chen YJ, Batchelor CL, Higginson JR, Suila H, Carpen O, Winder SJ (2004) Ezrin-dependent regulation of the actin cytoskeleton by betadystroglycan. Hum Mol Genet 13:1657-1668.

Stephens LE, Sonne JE, Fitzgerald ML, Damsky CH (1993) Targeted deletion of beta 1 integrins in F9 embryonal carcinoma cells affects morphological differentiation but not tissue-specific gene expression. J Cell Biol 123:1607-1620.

Sugita S, Saito F, Tang J, Satz J, Campbell K, Sudhof TC (2001) A stoichiometric complex of neurexins and dystroglycan in brain. J Cell Biol 154:435-445.

Sunada Y, Bernier SM, Kozak CA, Yamada Y, Campbell KP (1994) Deficiency of merosin in dystrophic dy mice and genetic linkage of laminin $\mathrm{M}$ chain gene to dy locus. J Biol Chem 269:13729-13732.

Sunada Y, Bernier SM, Utani A, Yamada Y, Campbell KP (1995) Identification of a novel mutant transcript of laminin alpha 2 chain gene responsible for muscular dystrophy and dysmyelination in dy2J mice. Hum Mol Genet 4:1055-1061.

Talts JF, Andac Z, Gohring W, Brancaccio A, Timpl R (1999) Binding of the $\mathrm{G}$ domains of laminin alpha1 and alpha2 chains and perlecan to heparin, sulfatides, alpha-dystroglycan and several extracellular matrix proteins. EMBO J 18:863-870.

Vabnick I, Novakovic SD, Levinson SR, Schachner M, Shrager P (1996) The clustering of axonal sodium channels during development of the peripheral nervous system. J Neurosci 16:4914-4922.

Vagnerova KT, Tarumi YS, Proctor TM, Patton BL (2003) A specialized basal lamina at the node of Ranvier. Soc Neurosci Abstr 29:351.18.

Weinberg HJ, Spencer PS, Raine CS (1975) Aberrant PNS development in dystrophic mice. Brain Res 88:532-537.

Wrabetz L, Feltri ML, Quattrini A, Imperiale D, Previtali S, D'Antonio M, Martini R, Yin X, Trapp BD, Zhou L, Chiu SY, Messing A (2000) P(0) glycoprotein overexpression causes congenital hypomyelination of peripheral nerves. J Cell Biol 148:1021-1034.

Yamada H, Denzer AJ, Hori H, Tanaka T, Anderson LV, Fujita S, Fukuta-Ohi H, Shimizu T, Ruegg MA, Matsumura K (1996) Dystroglycan is a dual receptor for agrin and laminin-2 in Schwann cell membrane. J Biol Chem 271:23418-23423.

Yang D, Bierman J, Tarumi YS, Zhong YP, Rangwala R, Proctor TM, Miyagoe-Suzuki Y, Takeda S, Miner JH, Sherman LS, Gold BG, Patton BL (2005) Coordinate control of axon defasciculation and myelination by laminin-2 and -8. J Cell Biol 168:655-666.

Yang JF, Cao G, Koirala S, Reddy LV, Ko CP (2001) Schwann cells express active agrin and enhance aggregation of acetylcholine receptors on muscle fibers. J Neurosci 21:9572-9584.

Yu WM, Feltri ML, Wrabetz L, Strickland S, Chen ZL (2005) Schwann cellspecific ablation of laminin $\gamma 1$ causes apoptosis and prevents proliferation. J Neurosci 25:4463-4472.

Yurchenco PD, Amenta PS, Patton BL (2004) Basement membrane assembly, stability and activities observed through a developmental lens. Matrix Biol 22:521-538. 